\title{
Adam Smith's theory of absolute advantage and the use of doxography in the history of economics
}

\author{
REINHARD SCHUMACHER \\ University of Potsdam, Germany
}

\begin{abstract}
This article reconstructs Adam Smith's theory of international trade and compares it with the way it is presented in modern textbooks as the theory of absolute advantage. This textbook presentation falls short of Smith's original ideas. I argue that the reason for this is the doxographic reconstruction of Smith's theory to fit him into a Whig history of international trade theory. In this way the historiography of international trade theory has falsely established Smith as a forerunner of modern neoclassical trade theory. I conclude by discussing to what extent Smith's insights can still be relevant today and what can be learnt from the mistreatment Smith has suffered in the historiography of international trade theory.
\end{abstract}

Keywords: Adam Smith, absolute advantage, international trade theory, history of economics, doxography, Whig history

JEL Classification: A11, A20, B12, B31, F10

Adam Smith is recognised as the founder of modern economics and as one of the first and most famous thinkers who argued in favour of free trade. However, his theory of international trade is rather poorly known or appreciated. Today most textbooks of economics in general-and of international trade in particular-start their introduction to trade theory with a short chapter on Adam Smith and the theory of absolute advantage, a theory allegedly invented by him. These texts then swiftly discard the absolute advantage theory in favour of a comparative advantage theory, which is connected to David Ricardo. However, Smith's writings include a more sophisticated theoretical approach to international trade than he is given credit for in the textbooks. In particular, his account shows that unrestricted trade and free

AuthoR's Note: I would like to thank Keith Tribe, Luis Mireles-Flores, and three anonymous referees for their extensive and very helpful comments and suggestions. 
international competition are more beneficial to a nation than the mercantilist economic policy that existed in many parts of Europe during the 18th century.

This article presents a deeper understanding of Smith's original ideas. Before I take a closer look at Smith's writings, I will briefly discuss the different methods used to reconstruct the ideas and theories of past thinkers. Then I will examine Smith's works, and compare them with the textbook version of his theory. The result is that Smith's original account differs widely from its textbook presentation. Textbooks use a deficient and illegitimate approach to the reconstruction of Smith's ideas, namely doxography. This approach has been used with the aim of including Smith in a cohesive history of international trade theory that leads straight to modern neoclassical theory. In the last section, I will discuss what modern economics can learn both from Smith's original ideas and from the way in which his theory has been misrepresented.

\section{RECONSTRUCTING PAST IDEAS}

Richard Rorty (1984) differentiates between four genres commonly used in the historiography of philosophy: historical reconstruction, rational reconstruction, Geistesgeschichte, and doxography. These genres are used to reconstruct past ideas and theories and can also be applied to historiography in other sciences. For example, Mark Blaug discusses their application in economic historiography and shows that they are "identical to recognizable styles in the history of economic thought" $(1990,27)$.

Historiography takes the form of historical reconstruction if the terms, problems, and theoretical approaches of past thinkers are described as they were intended in their original context. Writings are reconstructed in order to reproduce their original intended interpretation without seeing them through the eyes of subsequent discussions, theories, or paradigms (see Ziegler 2008, 3-6). The focus lies on what a past thinker actually said and what he or she meant with the analytical concepts, the theoretical approach, and the language he or she used. Thus, past ideas are portrayed in such a way that the discussed thinker would be able to join the discussion.

Rational reconstruction, in contrast, tries to dress up "past ideas in modern garb" (Blaug 2001, 150). It treats "the great dead thinkers of the past as contemporaries with whom we can exchange views" (Blaug 1990, 28). This approach might lead to a contortion of what the past thinker 
actually said. It can be charged with anachronism, since it focuses on what past thinkers would have said and what their implications would have been if they had used modern analytical tools. Thus, this approach takes historical texts and propositions out of context and evaluates them against current scientific understandings. However, this is not objectionable, if it is "conducted in full knowledge of [its] anachronism" (Rorty 1984, 53).

Geistesgeschichte (literally 'history of the spirit') resembles rational reconstruction, but takes place on a bigger scale. It "works at the level of problematics rather than of solutions to problems" (Rorty 1984, 57) and tries to identify "the past writers' central issues and their origin" (Johnson 1992, 22). Its objects of investigation are ideas rather than a single scholar. It "wants to give plausibility to a certain image" and as such is used for "canon-formation" (Rorty 1984, 57).

All three genres-historical reconstruction, rational reconstruction, and Geistesgeschichte-are to a certain extent "interdependent and complementary with one another" (Johnson 1992, 22). There is not necessarily a conflict among them. In practice, most reconstructions use a mix of them. Which approach is taken depends on the vantage point and on the question that should be answered. Yet, all three genres are legitimate approaches and essential for historiography. ${ }^{1}$

There is also, however, a fourth genre which Rorty terms doxography and which he argues is a deficient approach to reconstruction (see Rorty 1984, 61). Here, the ideas of a past writer are not just interpreted with respect to the historian's interests, but the discussed thinkers are 'decorticated'. The starting point of this approach is to question: what should a past thinker have said? In economics, this is "the attempt to describe theories of the past in terms of some form of modern economic theory under the presumption that the issue, purpose, and goals of past economists are the same" (Johnson 1992, 22). It proceeds as if a past economist had an implicit view on a modern topic, even if this deforms the author's original ideas. The problem with this approach is that past ideas are reinterpreted in such a way that they lose their original meaning and are adulterated. Doxography is different

\footnotetext{
${ }^{1}$ Rorty emphasises the relevance and legitimacy of these three approaches: "Rational reconstructions are necessary to help us present-day philosophers think through our problems. Historical reconstructions are needed to remind us that these problems are historical products, by demonstrating that they were invisible to our ancestors. Geistesgeschichte is needed to justify our belief that we are better off than those ancestors by virtue of having become aware of those problems" (Rorty 1984, 67-68).
} 
from a mere rational reconstruction. It attempts "to fit all texts into some recent orthodoxy to show that all those who have ever worked in the field have in substance treated exactly the same deep, fundamental questions" (Blaug 1990, 28).

\section{ADAM SMITH'S THEORY OF INTERNATIONAL TRADE}

The following analysis of Smith's theory is based predominantly on historical reconstruction. ${ }^{2}$ The main aim is to stay close to Smith's original writings in order to understand what Smith meant, rather than "what later generations would like him to have maintained" (Winch 1978, 5). To prevent misunderstandings, it should be pointed out that I will not conduct a contextual analysis on how Smith's theory developed, who influenced him, or the contemporary discussions in which Smith positioned himself. Therefore, the historical reconstruction will necessarily be incomplete. This is because the focus of this article does not lie in the development of Smith's thinking but in the comparison of his original theory with its presentation in modern textbooks. And to achieve this, an analysis of Smith's original texts is sufficient. $^{3}$

For Smith, international trade has the same underlying cause as all kinds of trade. In The wealth of nations ( $W N$ hereafter), trade is the consequence of the human "propensity to truck, barter, and exchange one thing for another" $\left(W N\right.$, I.ii.1). ${ }^{4}$ That does not mean that trade has no selfish motive. On the contrary, whenever people trade with each other they pursue their own interests, not some altruistic ones. They must benefit from trade otherwise they would not pursue it. Thus, merchants

\footnotetext{
2 In practice, historical reconstruction cannot clearly be separated from rational reconstruction (see Blaug 1990, 28-29). The approach used here includes elements of the latter to a minor extent in order to facilitate a contemporary reading. But this does not change the meaning of Smith's account. I will, for example, use the term 'international trade' though in the relevant texts Smith speaks instead of 'foreign trade'. Both terms describe the same phenomenon, but today the first term is more common. The term 'foreign trade' indicates that economics was considered more from a national point of view in Smith's lifetime. Smith was, like most economists of his time, a patriot, and as such he is primarily concerned with the well-being of Great Britain. Today, economists may have a less nationalistic attitude.

${ }^{3}$ This does not mean that a contextual analysis of Smith's foreign trade theory would be futile. On the contrary, it would be a worthwhile inquiry that, as far as I am aware of, has not yet been done.

${ }^{4}$ Smith gives two possible origins of this propensity. It might be "one of those original principles in human nature of which no further account can be given" or it could be "the necessary consequence of the faculties of reason and speech", which "seems more probable" ( $W N$, I.ii.2).
} 
carry on commerce internationally because they earn profits by it. However, Smith endeavours to show that not only single merchants but the society as a whole benefits from international trade. ${ }^{5}$

\section{The division of labour and its benefits}

Smith's thoughts on the division of labour constitute the basis for his theory of international trade. For him, it is the division of labour that leads to "the greatest improvement in the productive powers of labour" $(W N$, I.i.1). As a result of a more advanced division of labour, more output can be produced with the same amount of labour. He illustrates this point with his famous pin factory example, ${ }^{6}$ which shows that the division of labour produces an "increase of the quantity of work which $[\ldots]$ the same number of people are capable of performing" $(W N$, I.i.5). Then he identifies three reasons for this development:

first, [...] the increase of dexterity in every particular workman; secondly, [...] the saving of the time which is commonly lost in passing from one species of work to another; and lastly, [...] the invention of a great number of machines which facilitate and abridge labour, and enable one man to do the work of many ( $W N$, I.i.5).

The division of labour leads to quantitative and qualitative production improvements. This means that output is increased, technological development is stimulated, and workers' skills and productivity are enhanced. As a result, economic growth is promoted and national wealth increases. ${ }^{7}$ This can be summarised as "the more specialization, the more growth" (Staley 1989, 43).

The only limitation on the division of labour is "the power of exchanging", i.e., "the extent of the market" ( $W N$, I.iii.1). Consequently, if the market is expanded, an increase in the division of labour will be

\footnotetext{
${ }^{5}$ Though Smith wants to show that free international trade is generally best, his theory is also valid if trade is partly restricted. Smith himself is aware that complete free trade is unrealistic: "To expect, indeed, that the freedom of trade should ever be entirely restored in Great Britain, is as absurd as to expect that an Oceana or Utopia should ever be established in it. Not only the prejudices of the publick, but what is much more unconquerable, the private interests of many individuals, inevitably oppose it" (WN, IV.ii.43).

${ }^{6}$ In this example, ten workers, who are all assigned to specialised operations, can produce 48,000 pins a day, while one worker, who has to do all the separate operations on his own, can merely produce one pin a day ( $W N$, I.i.3).

${ }^{7}$ Smith defines wealth as "the annual produce of the land and labour of the society" $(W N$, Introduction).
} 
possible and, as a result, economic growth and wealth will increase. It is in this respect that international trade has to be considered.

\section{Gains from international trade}

According to Smith, international trade is advantageous for nations because

[it] gives a value to their superfluities, by exchanging them for something else, which may satisfy a part of their wants, and increase their enjoyments. By means of it the narrowness of the home market does not hinder the division of labour in any particular branch of art or manufacture from being carried to the highest perfection. By opening a more extensive market for whatever part of the produce of their labour may exceed the home consumption, it encourages them to improve its productive powers, and to augment its annual produce to the utmost, and thereby to increase the real revenue and wealth of the society ( $W N$, IV.i.31).

Here, Smith connects international trade to his ideas of the division of labour. If trade with another nation is established, an extension of the division of labour will be possible because the international market is bigger than the domestic market alone. International trade is thus advantageous to a nation because the enhanced division of labour leads to an increase "of the exchangeable value of the annual produce of the land and labour of the country" ( $W N$, IV.iii.c.3). This means that the real wealth of the nation and its population increases.

Controversy has arisen over Smith's statement that international trade "gives a value to their superfluities". This has become known as the "vent-for-surplus" gain, namely: that a nation can exchange its overproduction for other goods which are demanded. ${ }^{8}$ In this way, more of its population's wants and needs can be satisfied (as Smith mentions in various paragraphs of $W N$ ). However this "vent-for-surplus" concept is not a separate theory, as some suggest, but is merely an additional corollary of a wider (international) market. It is trade and the accompanying specialisation that create such surplus products in the first place. As a result of specialisation, each nation produces goods which cannot be sold domestically but must be exported.

\footnotetext{
${ }^{8}$ The term "vent-for-surplus" was introduced by John Stuart Mill $(1965,591)$.
} 
The "vent-for-surplus" gain is therefore complementary to Smith's international trade theory (see also Blecker 1997, 530). ${ }^{9}$

To recapitulate, international trade exploits the quantitative and qualitative benefits of an extended division of labour. International trade leads to an increase in specialisation that raises productivity through technical and organisational innovations. Thus, more goods can be produced overall with the same amount of labour. This boosts economic development as resources are activated and industry is encouraged (see Bloomfield 1975, 473). It is obvious that Smith's theory of (international) trade "is closely interwoven with his theory of economic development" (Myint 1977, 233). Trade and development cannot be separated in Smith's theory. They are linked through the division of labour.

The gains from international trade are reinforced by the increased competition that domestic producers are confronted with. This is another advantage, because international trade decreases the likelihood of domestic monopolies (see, e.g., $W N$, IV.vii.c.102). Smith argues that free competition, though often not in the interest of the producers, is always beneficial to the public (see $W N$, I.xi.p.10, IV.iii.c.11).

Smith also mentions an additional beneficial aspect of international trade, namely that it transfers knowledge and technology between different nations. The adoption and use of new production techniques lead to productivity growth and thus to economic development and an increase in wealth. Smith points out that these gains can even be more important to a nation than access to a wider market, especially for a big nation. He discusses this point with regard to China. China already has a large domestic market and would therefore primarily gain from open trade with Europe by getting access to its technology rather than by widening its market (see $W N$, IV.ix.40-41).

Overall, international trade is beneficial to both the individual nations and the world as a whole. Smith has an optimistic view of

\footnotetext{
${ }^{9}$ Myint distinguishes between two benefits from international trade in Smith's theory, which he labels "vent-for-surplus theory" and "productivity theory" (Myint 1958, 318) and argues that the former applies only to developing countries. However, Smith did not make such a separation. Some of Smith's remarks suggest that the production of one good can also yield another by-product for which a nation has no need of (WN, I.xi.c.3-4). In this sense, Kurz $(1992,478)$ applies the vent-for-surplus concept to "joint-product processes of production". Magnusson argues that the vent-for-surplus idea might only be applicable in the short-run because "it was very difficult in practice for the producers [...] to change from one kind of production to another" $(2004,46)$. For further discussions of Smith's vent-for-surplus 'theory', see Staley 1973; Kurz 1998, 79-82; Myint 1977; and Elmslie and Sedgley 2002.
} 
growth and economic progress. He never mentions any ceiling to the division of labour; and growth in his theory is boundless (see Darity and Davis 2005, 146-148). The division of labour is limited by the extent of the market, but the extent of the market is not limited in Smith's theory. Rather the market size itself depends on the division of labour and an extension of the division of labour leads in turn to a widening of the market (see Young 1928, 539-540). ${ }^{10}$

In general, it is always more advantageous to trade with a more developed nation that has a more mature economy, because it has a more developed and generally bigger market, which enables a more advanced division of labour. Since Smith is mainly concerned with Great Britain, he argues that free trade with France would be more beneficial than free trade with Portugal because France has a "superior opulence" and "would take more from us, and exchanging to a much greater value and in a much greater variety of ways, would encourage more industry in Great Britain and give occasion to more subdivisions of labour" (Smith 1978a, 578).

Smith's intention is to show that international trade is beneficial for all nations involved in trade. However, he concedes that nations do not necessarily benefit in equal parts: "trade which, without force or constraint, is naturally and regularly carried on between any two places is always advantageous, though not always equally so, to both" ( $W N$, IV.iii.c.2). Just as domestic trade is not equally beneficial to all regions within a country, international trade is not equally beneficial to all nations. Trade can even amplify differences between them, especially if they differ in their wealth. In line with this idea, in his Lectures on jurisprudence Smith compares the trade relations between a rich and a poor man to that between a developed and underdeveloped nation:

\footnotetext{
${ }^{10}$ Parts of Smith writings suggest that nations will finally reach a stationary state and fall apart (see WN, I.viii.24, III.iv.20). Smith stands in the tradition of David Hume and James Steuart and the "theory of growth and decay". However, Smith is not unambiguous here. Though Smith certainly acknowledges that all nations will finally vanish, he does not argue that there is a cap on economic development beyond which no nation is able to go before it withers away. China, according to Smith, has "been long stationary". It reached this stationary state at least "five hundred years ago [...] perhaps even long before" ( $W N$, I.viii.24). However, China could boost its economic growth and leave this stationary state by adopting technologies from Europe (see $W N$, IV.ix.40-41). Thus, China's stationary state is not caused by any a natural ceiling on economic development but rather by "the nature of its laws and institutions" ( $W N$, I.viii.24).
} 
When a rich man and a poor man deal with one another, both of them will encrease their riches, if they deal prudently, but the rich man's stock will encrease in a greater proportion than the poor man's. In like manner, when a rich and a poor nation engage in trade the rich nation will have the greatest advantage, and therefore the prohibition of this commerce is most hurtfull to it of the two (Smith 1978b, 512).

\section{Domestic growth and the patterns of international trade}

Smith argues that domestic and international trade are determined by the same rules. The division of labour works internationally the same way it does domestically. A nation, therefore, specialises in the production of some goods while buying other goods from abroad. This is beneficial to a nation: "If a foreign country can supply us with a commodity cheaper than we ourselves can make it, better buy it of them with some part of the produce of our own industry employed in a way in which we have some advantage" (WN, IV.ii.12).

This means that a nation produces and exports those commodities which it can produce more cheaply than other nations, and imports those which it cannot. A nation will not produce a good that is produced more expensively at home than abroad-be it "a thirtieth, or even a three hundredth part more" (WN, IV.ii.15). As a result, international trade develops in the same way as domestic trade: "Were all nations to follow the liberal system of free exportation and free importation, the different states into which a great continent was divided would so far resemble the different provinces of a great empire" (WN, IV.v.b.39). ${ }^{11}$ If free trade is operative, consumers will buy a good from whoever sells it at the lowest price. The nation (or producer) with the lowest production costs is able to sell it cheaper than every other producer and

\footnotetext{
${ }^{11}$ Smith differentiates foreign trade from domestic trade by its slower rate of turnover of capital, which is due to the greater time it takes to cover the greater distances involved in international transactions (see $W N$, II.v.27). However, this general rule does not apply for neighbouring countries, as he demonstrates using the example of England and France. Trade between Southern England and Northern France has roughly the same frequency of returns as domestic English trade, and for Southern England it therefore makes no difference if it trades with Northern France or the rest of England (see $W N$, IV.iii.c.12). Furthermore, Smith differentiates production according to "the quantity of [productive] labour, which equal capitals are capable of putting into motion" ( $W N$, II.v.1). According to Smith, production for domestic consumption generally puts more productive labour into motion at home than does production for international trade. On this, see also Tribe 2006.
} 
is able to undersell its competitors. ${ }^{12}$ Therefore, every nation will produce those commodities which it can produce more cheaply than other countries.

Production costs are-according to Smith-all those incurred by bringing a product to the market. They include transport costs. Smith emphasises the importance of transport costs frequently in reference to international trade (see, e.g., $W N$, I.xi.c.5, IV.i.29, IV.ii.16, IV.ix.41). This means that different nations can each have an absolute advantage in the same good in different (domestic) markets, taking into account the transport costs from the place of production to the market in which it is sold.

As a result, the direction of international trade is determined by the current absolute production cost advantages, i.e., the costs that arise in producing a good and bringing it to the market. Nations will automatically specialise according to their respective advantages if trade is unrestricted. International competitiveness is determined in the same way as competitiveness inside a nation, i.e., by price advantages.

What are the origins of such advantages? Smith recognises that there are some differences between countries that yield specialisation. These include a nation's "soil, climate, and situation" as well as its "laws and institutions" ( $W N$, I.ix.15) and its means of communication and transport (see WN, III.iv.20, IV.ix.41). However, Smith's overall approach towards specialisation is that trade and the division of labour lead to specialisation and not the other way around. He argues that specialisation is in most cases not the cause but "the effect of the division of labour" ( $W N$, I.ii.4). He gives the example of a philosopher and a street porter who "were, perhaps, very much alike" ( $W N$, I.ii.4) in their early childhood. The difference between them arose with their education for different jobs and continued to widen while they pursued those professions.

The same applies to the specialisation of nations. Thus, trade between nations is, in general, not based on the differences between them that existed prior to trade. Rather, it is trade which leads to specialisation and differences. Differences between nations, then, are

${ }^{12}$ During Smith's lifetime, mainly merchants were engaged in international trade. Their chief concern was the money price of a commodity because their intention was to sell goods in order to make profits, i.e., to get high returns on their capital (see, e.g., $W N$, I.v.20, II.v.14, II.v.37). At this time, transnational companies did not exist, nor were average citizens involved in international trade. There were companies that operated in different parts of the world, but they were chartered companies that operated only inside colonial empires and were organised along mercantilist lines. 
mainly due to the level of a nation's division of labour, and thus of its productivity and its technology, rather than due to natural differences. The production cost advantages of a nation mainly develop endogenously, through the market-widening effects of international trade (see Blecker 1997, 534).

There is thus a mutual relationship between international trade and domestic economic development. They are dependent on each other and each impact the pattern of trade. A nation's production cost advantage "is endogenously determined by its development path, which is in turn affected by its trade pattern" (Maneschi 1998, 48). Both international trade and domestic development affect the division of labour. As a result, the absolute production cost advantages of a country are not fixed. They tend to be amplified by trade. And they may also change over time. A nation can gain an absolute advantage in the production of a good, for example, or it can lose such an advantage-like a producer in a domestic market.

To sum up this section, Adam Smith's theory of international trade is dynamic in that it is integrated into the broader economic framework of the division of labour. It considers economic growth that results from and affects international trade. Absolute production cost advantages and the division of the benefits from trade are not fixed once and for all. Rather, they develop and emerge endogenously as a result of trade.

\section{ABSOLUTE ADVANTAGE IN MODERN TEXTBOOKS}

Subsequent economists did not pay much attention to Smith's theory of international trade. In general, it is not seen as relevant because of the predominance of the theory of comparative advantage, which "has been the bedrock on which all subsequent developments in the theory of international trade have rested" (Maneschi 1998, 10). As a result, Smith's theory was barely noticed and not developed any further. Nonetheless, many of today's textbooks deal briefly with the theory of absolute advantage, which is ascribed to Smith. They portray Smith's theory as "a stepping-stone to a more sophisticated theory" (Staley 1989, 52), namely the theory of comparative advantage that is attributed to David Ricardo. Following this, most textbooks discuss the merits and failings of the Ricardian model and introduce the neoclassical version of the theory of comparative advantage, including the Heckscher-Ohlin model and the factor price equalisation theorem. In this way, Smith's theory is presented as the starting point of a theoretical development that leads 
directly to neoclassical trade models. Smith's concerns and ideas are thus aligned with those of neoclassical trade theories. However, they are dwarfed by the theory of comparative advantage, which is one of the most praised theories in economics.

The theory of absolute advantage itself is normally presented with an example of two countries and two commodities (2x2 model). Each nation can produce one good with less expenditure of human labour than the other and thus more cheaply. As a result, each nation has an absolute advantage in the production of one good. An example is given in Table 1: Nation A has an absolute advantage in the production of commodity 1 because it needs only 3 labour days to produce one unit of it while Nation B needs 6 labour days. Nation B has an absolute advantage in commodity $2 .{ }^{13}$

Table 1: textbook example of absolute advantages

\begin{tabular}{|c|c|c|}
\hline $\begin{array}{c}\text { Days of labour required to } \\
\text { produce one unit of }\end{array}$ & Nation A & Nation B \\
\hline Commodity 1 & 3 & 6 \\
\hline Commodity 2 & 8 & 4 \\
\hline
\end{tabular}

If both nations start trading with each other, each nation will specialise in the production of the good it has an absolute advantage in and obtain the other commodity through international trade. More units of both commodities can be produced overall because the given resources are utilised more efficiently. Through trade, both nations are able to consume more units of at least one commodity. In our example, Nation A would specialise completely in commodity 1, and Nation B in commodity 2. There are no further gains from international trade besides this one-off increase in the overall production and thus consumption. Nothing more happens.

\footnotetext{
${ }^{13}$ For similar examples using unit labour inputs, see Bieling 2007, 35; Chacholiades 2006, 16-19; Eicher, et al. 2009, 14-16; Engelkamp and Sell 2011, 328-330; Heine and Herr 2003, 617; Koo and Kennedy 2005, 11-13; Mankiw and Taylor 2006, 51; Söllner 2008, 213-214; Wildmann 2010, 58-59; Zhang 2008, 24-25. Others use the reciprocal value, which shows how many units can be produced per labour year, e.g., David and Stewart 2010, 11-12; Markusen, et al. 1995, 69; Mehmet 1999, 46-48; Peng 2011, 151152; or per labour hour, e.g., Carbaugh 2011, 32-33; Ingham 2004, 12; Salvatore 2011, 35-37. Still others use of labour productivity in general, e.g., Ison and Wall 2007, 393394; Kjeldsen-Kragh 2002, 11-12; Ströbele and Wacker 2000, 9; Yarbrough and Yarbrough 2006, 27-28. This list is far from being complete. There are many more textbooks that use such numerical examples. The economics textbooks listed here are considered representative.
} 
The presentation of Smith's international trade theory in textbooks is essentially standardised and does not vary significantly. Textbooks emphasise that the theory of absolute advantage "can explain only a small part of world trade" (Salvatore 2011, 37). Thus, it is seen as a special case of the theory of comparative advantage and both theories are seen as complementary (see Dieckheuer 2001, 50). Smith is often criticised for not being able to come up with the more sophisticated theory of comparative advantage (see Zhang 2008, 3). In comparison to Ricardo, Smith is described as a "poor trade theorist" and his theory as a "naive theory" (Mehmet 1999, 47).

However, the textbook account does not fairly represent Smith's theory. ${ }^{14}$ In particular, as claiming that trade is only beneficial because it leads to an increase in the amount of both commodities that can be produced with existing production technology and capabilities. This falls short of Smith's theory and is not merely a simplification of it but a false interpretation. The textbooks only present a comparison of two static situations, namely before and after the opening of trade. Smith himself neither uses such a comparison nor does he give a numerical example of this kind. Furthermore, gains in the form of technological change and economic growth are excluded altogether. Thus, the modern presentation lacks the depth of Smith's original theory.

A useful way to understand this type of distorted account is to note that it conforms with Quentin Skinner's (1969) notion of mythology. Skinner distinguishes mythologies from proper history or historiography. They are characterised by historical absurdity. Mythology is defined by Skinner as a methodology for writing history which "can scarcely contain any genuinely historical reports about thoughts that were actually thought in the past" (Skinner 1969, 22). Mythologies are exercises in doxography and therefore Skinner's concept can be used to understand how modern economics uses

\footnotetext{
${ }^{14}$ It should be added that not all textbooks are guilty of this misrepresentation. Some textbooks forgo Smith in their treatment of the historical development of trade theory, mainly because they reject the idea that the theory of absolute advantage can explain any part of international trade, e.g., Krugman and Obstfeld 2009. On the other hand, there is, for example, a book by Douglas Irwin (2009), which includes Smith's dynamic gains and gives a more accurate account of Smith's theory. Irwin does not reduce Smith's approach to a static numerical illustration of absolute advantage. However, such a book is the exception that proves the rule. By far the majority of textbooks misrepresent Smith. And even Irwin argues that "the standard gains" from trade, according to Smith, result from the use of "limited productive resources (such as land, labor, and capital) more efficiently" (Irwin 2009, 40).
} 
doxography to reconstruct Smith. ${ }^{15}$ Mythologies are repeated over and over again and thereby become an integral part of the historiography of a subject and thus part of the collective knowledge of the scientific community.

The textbook presentation of the theory of absolute advantage can be classified as a mythology in Skinner's sense. He defines different types of mythologies, several of which are used by textbooks, namely the mythology of doctrines and the mythology of prolepsis. First, only a fraction of Smith's theory of international trade, namely that countries specialise according to absolute production cost advantages, is used and it is reinterpreted into an entirely different theory. This exemplifies the first type of the mythology of doctrines: "mistaking some scattered or incidental remarks by one of the classic theorists for his 'doctrine' on one of the themes which the historian is set to expect" (Skinner 1969, 7). Second, the charge or criticism that Smith did not identify the mechanism of comparative advantage and failed to come up with this theory exemplifies the second type of the mythology of doctrines because it presupposes that he tried to (see Skinner 1969, 12-16). Third, because it describes Smith's "work and its alleged significance in such a way that no place is left for the analysis of what the author himself meant to say" (Skinner 1969, 22) the presentation of the theory of absolute advantage also exemplifies the mythology of prolepsis.

Thus, what economic textbooks present is not a legitimate anachronism which could be the basis of proper rational reconstruction or Geistesgeschichte. Rather, they adulterate Smith's theory and use the deficient methodology of doxography to reconstruct it.

\section{A WHIG HISTORY OF INTERNATIONAL TRADE THEORY}

In order to understand why modern textbooks use doxography to reconstruct Smith's ideas one has to understand how the history of international trade theory is written. As was shown above, Smith is discussed at the beginning of a linear theoretical development that leads directly to the neoclassical formulation of the theory of comparative advantage. As a result, Smith's theory of international trade is adjusted in order to fit into the story of modern economics and, thus, into the

\footnotetext{
15 Though Skinner's approach to the legitimacy of historiography is stricter than Rorty's, mythologies in Skinner's sense present modes of doxography as defined by Rorty. See also Rorty 1984, who discusses and relates his own genres to Skinner.
} 
neoclassical paradigm. This paradigm, which is based on marginal analysis, dominates international economics.

Neoclassical theory is the vantage point of the most important and the most widely read textbooks in international economics. Smith is construed "as a forerunner to Ricardo's theory of comparative advantage" (Kjeldsen-Kragh 2002, 89) and, thus, as a precursor of contemporary neoclassical international trade theory. From this vantage point, Smith's ideas are seen as rudimentary and incomplete. Smith himself is not regarded as an ingenious trade theorist and he is criticised for having failed to discover the principle of comparative advantage. In this story, his theory was improved on first by Ricardo (and other classical economists), whose theories were in turn further developed by neoclassical economists. The history of international economics starts with Adam Smith and evolves step by step up to today's standard trade models. It is argued that Smith, together with Ricardo, laid the foundations of modern trade theory.

Since neoclassical thinking dominates current economics, it also dominates the writing of economic history. Neoclassical economists can choose their predecessors, i.e., who are seen as forerunners of its theoretical approach. "Winners" are able to write the history of their subject. ${ }^{16}$ This, however, is not a sufficient reason to reject a historiography as doxography. It is an established method of Geistesgeschichte and rational reconstruction to interpret and represent the history of a subject as a Whig history (Blaug 2001, 151). A Whig history claims a linear development from past to modern theories, leaving out anything that does not fit into the story. However, if past theories are misrepresented and their original meanings are changed considerably in order to fit them into such a Whig history, this does not constitute a legitimate reconstruction.

A Whig history without any historical reconstructions to keep it honest can easily turn into doxography, as is the case with Smith's theory of international trade. His ideas are reconstructed deficiently and his theory is adulterated to suit the neoclassical history of international trade theory. Such a reconstruction is, in Skinner's words, "a means to fix one's own prejudices on to the most charismatic names, under the guise of innocuous historical speculation. History then indeed becomes

\footnotetext{
${ }^{16}$ Rorty stresses this point: "Like the history of anything else, history of philosophy is written by the victors. Victors get to choose their ancestors, in the sense that they decide which among their all too various ancestors to mention, write biographies of, and commend to their descendants" $(1984,70)$.
} 
a pack of tricks we play on the dead" (1969, 13-14). Smith has suffered such a treatment in economics before as the father of free trade. Magnusson (2004) shows how, in a similar Whig history also relying on doxography, the tradition of free trade that was invented and established in the 19th and 20th century made Smith the alleged founder of its ideological movement.

\section{How Smith's theory has been altered}

In order to be included in the Whig history of international trade theory, Smith's ideas are fitted into the neoclassical paradigm of the theory of comparative advantage. This is why there results such a discrepancy between Smith's original ideas and their deformed representation in modern textbooks. Smith's ideas are taken out of their contexts and imported into another theoretical framework. To achieve this goal, two main alterations of Smith's approach have been required.

First, his approach has to be translated into a static setting. In contrast to Smith's dynamic approach, later trade theory is predominantly static. Shortly after Smith's death "Ricardo and J. S. Mill increasingly formalized the international trade element of classical economics in terms of the static theory of efficient allocation of given resources" (West 1988, 20). This static approach prevails in the neoclassical theory of international trade. As a result, international trade theory focuses on efficient resource allocation, whereas Smith includes this only as a minor advantage of free international trade. In this respect, neoclassical trade theory falls short of Smith's theory. Smith's approach was, however, reformulated to fit into this static framework. His trade theory was dissociated from economic development so that it could be illustrated by the comparison of two static states, one before and one after the countries started trading. In this illustration, each nation has an absolute advantage in the production of at least one commodity. This framework leaves no room for dynamic developments.

The second alteration is that Smith's approach is fitted into the "Ricardian logic of trade". Buchanan and Yoon (2002) identify two logics of trade, which they label Smithian and Ricardian. The Smithian logic of trade is characterised by the assumption that countries do not need to be different before they start trading. It is through trade and the subsequent specialisation that countries start to differ in their production. Advantages emerge and develop endogenously as a result 
of trade. It follows, as shown, that Smith's dynamic approach towards trade is coupled with growth. The reason for this is that specialisation leads to an enhanced division of labour and a positive feedback mechanism.

The Ricardian logic, on the other hand, assumes that countries already differ before they start trading. Differences between countries are the only reason why trade takes place, and these do not change after nations start trading. According to this logic, advantages are exogenously given before trade takes place and are not influenced by trade. The Ricardian logic dominates the theory of comparative advantage while the Smithian logic is rejected or ignored. As part of the Whig history of international trade theory, Smith's approach is fitted to the Ricardian logic, and the self-reinforcing mechanism of the division of labour is discarded. That is, textbooks mistakenly argue that Smith assumes that each nation needs an absolute advantage in the production of at least one good to benefit from trade. Moreover, they claim that absolute advantages are given prior to trade-otherwise trade would not be possible-and that those absolute advantages do not change or develop after trade is established (see, e.g., Mehmet 1999, 47).

\section{How Smith was incorporated into modern trade theory}

The historiography of international trade theory incorporated Smith step by step. His direct successors did not value his trade theory highly. John Stuart Mill $(1965,591-593)$ largely argued against Smith's vent-forsurplus approach, and others saw Smith as a poor trade theorist (e.g., Bastable 1897; Hollander 1910; Angell 1926). ${ }^{17}$ But gradually Smith's contribution came to be valued more highly-in line with his scientific authority - and he was interpreted as a direct forerunner of the theory of comparative advantage. Many have argued that he paved the way for Ricardo (see, e.g., Kobatsch 1907; Eßlen 1925; Bickel 1926; Viner 1931 and 1937; Sinclair 1932; Haberler 1933; Young 1938; Killough 1938; Samuelson 1948). Although it was noticed that Smith's starting point was the division of labour, rather than static advantages, the division of labour argument itself became more and more appropriated by the Ricardian logic of trade (see, e.g., Kobatsch 1907; Litman 1923; Harrod 1933; Young 1938; Killough 1938).

\footnotetext{
${ }^{17}$ As noted above, Smith is also widely seen as a poor trade theorist today. The difference is that today his theory is seen as an important part of the development of modern trade theory, while previously his theory was rejected altogether.
} 
The concept of absolute advantage was first used by economists, without referring to Smith, to explain the theory of comparative advantage (see, e.g., Mill 1965 and 1967; Cairnes 1874; Bullock 1913), sometimes with numerical examples (see, e.g., Griffin 1924; Taussig 1927; Sinclair 1932; Haberler 1933). This changed, however, and Smith's name was connected to the concept of absolute advantage (see, e.g., Eßlen 1925; Bickel 1926; Viner 1931 and 1937). By the 1950s and 1960s, this view had become generally accepted and incorporated into textbooks (see, e.g., Harris 1957; Wasserman and Hultman 1962; Wexler 1968).

Numerical examples like the one discussed above were also, wrongly, attributed to Smith (see, e.g., Wexler 1968; Södersten 1970; Adams 1972). Such numerical examples imply both a static approach and the Ricardian theory of trade. With their help, Smith's theory was established as a precursor of the theory of comparative advantage, which is normally illustrated by a numerical example. ${ }^{18}$ The use of a similar, though more primitive, numerical example insinuates that Smith used the same method, though in a less elaborate way. This misleading numerical illustration of Smith's theory thus helped to establish the idea of Smith as a direct forerunner of later classical and neoclassical theory.

Other assumptions used by neoclassical trade theory are similarly ascribed to Smith's theory so that it fits well into the Whig history. For example, textbooks wrongly claim that Smith assumes unrestricted domestic mobility of labour and capital. Actually, Smith assumes that neither factor of production is perfectly mobile, whether domestically or internationally. In both cases they are assumed to be only partly mobile. ${ }^{19}$ Another example is transport costs. As shown above, they play an important role in Smith's trade theory. However, textbooks falsely assert that Smith abstracts from transport costs as neoclassical models do. This claim was established long ago and is repeated in modern textbooks (see, e.g., Viner 1937, 440; Engelkamp and Sell 2011, 329).

\footnotetext{
18 Such numerical examples have been part of the presentation of the theory of comparative advantage ever since Ricardo's formulation of it. Ricardo's own formulation used an example with two countries and two commodities. However, today's numerical examples more resemble John Stuart Mill's numerical presentation than Ricardo's.

${ }^{19}$ Capital can exist in the form of "buildings or in lasting improvement of lands" ( $W N$, III.iv.24), which hinders its mobility. Labour is also not perfectly mobile because humans are not willing to move freely and often: "After all that has been said of the levity and inconstancy of human nature, it appears evidently from experience that a man is of all sorts of luggage the most difficult to be transported" (WN, I.viii.31). See also Bloomfield 1975, 460.
} 
In this way, doxography became an integral part of the "official" or mainstream history of international trade theory. Today, Smith is universally connected to the theory of absolute advantage and as such he is seen as a pioneer of the theory of comparative advantage. This is a commonplace in economics nowadays and part of many reference works like economic handbooks and encyclopaedias (see, e.g., Jones 2001; Reinert and Rajan 2009; Rutherford 2000).

\section{The use of doxography in the history of international trade}

The question remains, why did neoclassical economists use doxography in this particular case? There are two main reasons, namely legitimacy and custom. As to legitimacy, Smith has a "well established reputation as the founder of modern economics" (Tribe 1999, 609). He is renowned and eminently respectable, not only in economics but also in social science as a whole (see Winch 1978, 6). Sceptical readers are more likely to be convinced if one can claim that an established scholar with a high reputation supports one's argument; the status of one's own theory gets more authority inside the scientific community. Therefore, a theory of international trade that refers to Smith increased legitimacy and acceptance. Smith is used by neoclassical trade theory as "as a source of intellectual support" (Magnusson 2004, 23). In this way, Smith "can be regarded as a victim of his own fame and success" (Magnusson 2004, 23). Since Smith was already established as the founder of the free trade movement (see Magnusson 2004), it was convenient to also make him the father of the theory that is primarily used to support free trade, namely the theory of comparative advantage. As a result, Smith is not only seen as a forerunner but even as laying the foundations of neoclassical international trade theory, even though this theory has nearly nothing in common with Smith's actual ideas.

As to custom, Smith's name has been connected to the textbook theory of absolute advantage by virtually all (trade) economists in the history of the discipline. Smith's theory is misrepresented in the present, because it was misrepresented in the same way in the past. As Stigler notes: "If a theory once acquired an established meaning, each generation of economists bequeaths this meaning to the next, and it is almost impossible for a famous theory to get a fresh hearing" (1958, 367). It is questionable whether every textbook author takes the trouble to read Smith's economic opus from beginning to end. Rather most authors get their information about Smith's ideas from secondary 
or tertiary sources, and thus merely repeat what is thought to be in Smith's original texts. Smith's misrepresentation is repeated over and over again and is thus reinforced.

\section{WHAT ARE THE LESSONS?}

After discussing different methods of reconstructing the ideas of past economists, I turned to Adam Smith's approach towards international trade and compared it with its presentation in economic textbooks. I found a great difference between Smith's original ideas and the textbook version. As was shown, neoclassical economists use their theoretical framework to reinterpret Smith's theory in a way that fits their "preconceived ideas of what modern economics ought to be about" (Johnson 1992, 23). Smith's complex approach towards international trade is translated into a different theoretical framework. The history of economic analysis is reduced "to an elegant theoretical exercise in historical positivism" (Johnson 1992, 23). We can now ask what international trade theory can learn from Smith's original ideas and from the way his legacy was treated.

In the last decades, new trade theory has criticised the narrowness of standard trade models and tried to enhance them with new models and assumptions. This can be seen as a movement in the direction of Smith's original ideas. ${ }^{20}$ New trade theory focuses on issues long neglected by mainstream trade theory, most famously economies of scale or increasing returns, technological change, and other productivity effects (see, e.g., Krugman 2002 and 1990; Fujita, et al. 1999). Similarly to Smith, it is recognised that "inherent advantages to specialization" (Krugman 1990, 2) play an important role. Economies of scale, technological change and learning by doing are included in most of today's textbooks, mainly described as a supplement to the theory of comparative advantage. In this way, some of Smith's insights, though not Smith himself, have been reappraised and are again acknowledged by mainstream trade theory.

\footnotetext{
${ }^{20}$ Krugman interprets it in this way by saying that the "long dominance of Ricardo over Smith-of comparative advantage over increasing returns" $(1990,4)$ is over and both are now seen as more or less equivalent. However, textbooks do not normally connect increasing returns to Adam Smith. Additionally, new trade theory does not refer directly to Smith, and it developed mainly without considering him. However, many new trade theory models could claim Smith, at least partly, as a progenitor because they raise similar issues.
} 
However, Smith's ideas, though only rudimentarily theorised by today's standards, can still be a source of inspiration for modern trade theory. His dynamic perspective can be a useful starting point. His concept of the division of labour and the resulting positive feedback mechanism are much richer and more complex than the neoclassical concept of economies of scale. ${ }^{21}$ The connection between trade and growth that is part of Smith's approach deserves more attention. In Smith's approach both production cost advantages and technological change develop endogenously as a result of trade. Most contemporary models still assume that these are exogenously given. For Smith, the division of labour is central and self-reinforcing. Endogenous development results directly from trade: a market expansion leads to a more advanced division of labour, which in turn leads to further market expansion.

This dynamic approach goes beyond both static gains and the Ricardian logic of trade. It entails permanent change and development. Another thought that might be worth considering is that it is more beneficial for a rich, industrial nation to trade with another rich, industrial nation, rather than a poor one, because its bigger market allows for a more advanced division of labour. In contrast, the standard theory of comparative advantage argues the converse, namely that an industrial, relatively capital-rich country benefits most from trade with a poorer, relatively labour-rich country. Smith's claim that a rich country gets a greater share of the benefits from trade with a poor country might also be worth some consideration.

Additionally, lessons can be drawn from the use of doxography in the reconstruction of Smith's trade theory. Smith's insights were reinterpreted into a neoclassical framework and fitted into a Whig history of international trade. This version of Smith is merely used to reflect the dominant thinking. Instead of advancing his original ideas, trade theory forgot them. By using doxography rather than a more adequate genre of historiography, the chance to learn from Smith was missed. Though mainstream trade theory improved the formalisation and predictive power of trade models, they ignored at the same time some of the most important issues of international trade, which with

\footnotetext{
${ }^{21}$ The neoclassical concept of increasing returns implies that when all factor inputs are increased by an identical proportion, output increases in a greater proportion. Furthermore, textbooks often fit increasing returns and technological developments into a static approach and into the Ricardian logic of trade which still prevails in neoclassical theory.
} 
Smith had dealt. ${ }^{22}$ It took a long time for ideas, which Smith had put forward nearly 250 years ago, to be again considered by mainstream trade theory.

This article has shown that reconstructing Smith's economic ideas based on one's prejudices about his intentions can easily lead to an interpretation that is historically meaningless. An honest historical reconstruction of Smith's approach towards international trade, on the other hand, can show how his ideas can still be interesting for modern economics. Contemporary economics can benefit from proper historiography. Though his overall approach might be outdated, it is still worthwhile to study Smith because doing so may spur a new perception of a given phenomenon. As was shown, Smith's misrepresentation is firmly established in international economics. It will be hard to establish a more adequate presentation of Smith's original trade theory. It is, however, not impossible and well worth trying.

\section{CONCLUSION}

In this article, it was argued that economic textbooks use doxography to interpret Smith's ideas on international trade. Smith's original theory was discussed and compared to its representation in modern textbooks. It was shown that these textbooks do not reproduce Smith's theory slightly inaccurately, but adulterate it completely. They attempt "to impose a canon on a problematic constructed without reference to the canon" (Rorty 1984, 62). The static neoclassical canon is imposed on Smith's dynamic trade and growth theory, which is constructed neither as a static model nor with neoclassical assumptions. Likewise, the Ricardian logic of trade is imposed on Smith's 'trade-cum-specialisation' approach, which is based on a very different logic. In this way, Smith is fitted into a Whig history of international trade theory, and his name is misleadingly attached to the textbook theory of absolute advantage.

It is, however, not uncommon in science for a name to be wrongly attributed to a theory or concept. This phenomenon is known as "Stigler's Law of Eponymy", which states that "[n]o scientific discovery

\footnotetext{
${ }^{22}$ Krugman (1990; 2002), for example, argues that elaborate concepts and ideas were disregarded by neoclassical economists because they could not be formalised with the mathematical models existing at the time. In the case of trade theory, formalisation can thus be seen both as a step forward and as a step backwards at the same time.
} 
is named after its original inventor" (Stigler 1980, 147). ${ }^{23}$ Usually, this mistaken appreciation is a somewhat undeserved honour. Eponymy after all is "a mnemonic and a commemorative device" that is "the most enduring and perhaps most prestigious kind of recognition institutionalized in science" (Merton 1973, 300). But in our case, Smith is not the mistaken recipient of an undeserved honour. Rather, Adam Smith's theory of absolute advantage is a huge diversion from the recognition that Smith's original ideas deserve.

\section{REFERENCES}

Adams, John. 1972. International economics: a self-teaching introduction to the basic concepts. London: Longman.

Angell, James W. 1926. The theory of international prices: history, criticism, and restatement. Cambridge (MA): Harvard University Press.

Bastable, Charles F. 1897. The theory of international trade: with some of its applications to economic policy. London: Macmillan.

Bickel, Wilhelm. 1926. Die Ökonomische Begründung der Freihandelspolitik: Eine Dogmenhistorische Untersuchung. Zürich: Girsberger.

Bieling, Hans-Jürgen. 2007. Internationale Politische Ökonomie: Eine Einführung. Wiesbaden: VS Verlag für Sozialwissenschaften.

Blaug, Mark. 1990. On the historiography of economics. Journal of the History of Economic Thought, 12 (1): 27-37.

Blaug, Mark. 2001. No history of ideas, please, we're economists. The Journal of Economic Perspectives, 15 (1): 145-164.

Blecker, Robert A. 1997. The 'unnatural and retrograde order': Adam Smith's theories of trade and development reconsidered. Economica, 64 (255): 527-537.

Bloomfield, Arthur I. 1975. Adam Smith and the theory of international trade. In Essays on Adam Smith, ed. Andrew S. Skinner, and Thomas Wilson. Oxford: Clarendon Press, 455-481.

Buchanan, James M., and Yong J. Yoon. 2002. Globalization as framed by the two logics of trade. The Independent Review, 6 (3): 399-405.

Bullock, Charles Jesse. 1913. The elements of economics. Boston: Silver.

Cairnes, John E. 1874. Some leading principles of political economy newly expounded. New York: Harper \& Bros.

Carbaugh, Robert J. 2011. International economics. Mason (OH): South-Western Cengage Learning.

Chacholiades, Miltiades. 2006 [1973]. The pure theory of international trade. Piscataway (NJ): Aldine Transaction.

\footnotetext{
${ }^{23}$ This is true for Stigler's law of eponymy itself, which was first stated by Robert K. Merton. It is also true of many cases of eponymy in international trade theory besides Smith's theory of absolute advantage. Cases of this law include, for example, Ricardo's theory of comparative advantage (the way it is commonly known today was first phrased only later by J. S. Mill; additionally Torrens formulated this theory similarly shortly before Ricardo), the Ricardian model and the Heckscher-Ohlin model. There are also exceptions where this law does not apply, e.g., the Lerner-Samuelson theorem.
} 
Darity, Williman A. Jr., and Lewis S. Davis. 2005. Growth, trade, and uneven development. Cambridge Journal of Economics, 29 (1): 141-170.

David, Pierre A., and Richard D. Stewart. 2010. International logistics: the management of international trade operations. Mason $(\mathrm{OH})$ : South-Western Cengage Learning.

Dieckheuer, Gustav. 2001. Internationale Wirtschaftsbeziehungen. München: Oldenbourg.

Eicher, Theo S., John H. Mutti, and Michelle H. Turnovsky. 2009. International economics. London: Routledge.

Elmslie, Bruce, and Norman Sedgley. 2002. Vent for surplus: a case of mistaken identity. Southern Economic Journal, 68 (3): 712-720.

Engelkamp, Paul, and Friedrich L. Sell. 2011. Einführung in die Volkswirtschaftslehre. Berlin: Springer.

Eßlen, Joseph B. 1925. Die Politik des Auswärtigen Handels: Ein Lehrbuch. Stuttgart: Enke.

Fujita, Masahisa, Paul R. Krugman, and Anthony J. Venables. 1999. The spatial economy: cities, regions, and international trade. Cambridge (MA): MIT Press.

Griffin, Clare E. 1924. Principles of foreign trade. New York: Macmillan.

Haberler, Gottfried. 1933. Der Internationale Handel: Theorie der Weltwirtschaftlichen Zusammenhänge sowie Darstellung und Analyse der Aussenhandelspolitik. Berlin: Julius Springer.

Harris, Seymour E. 1957. International and interregional economics. New York: McGrawHill.

Harrod, Roy F. 1933. International economics. London: Nisbet.

Heine, Michael, and Hansjörg Herr. 2003. Volkswirtschaftslehre: Paradigmenorientierte Einführung in die Mikro- und Makroökonomie. München: Oldenbourg.

Hollander, Jacob H. 1910. David Ricardo: a centenary estimate. Baltimore: Johns Hopkins Press.

Ingham, Barbara. 2004. International economics: a European focus. London: Prentice Hall-Financial Times.

Irwin, Douglas A. 2009. Free trade under fire. Princeton (NJ): Princeton University Press. Ison, Stephen, and Stuart Wall. 2007. Economics. London: Prentice Hall-Financial Times.

Johnson, L. E. 1992. The source of value and Ricardo: an historical reconstruction. Atlantic Economic Journal, 20 (4): 21-31.

Jones, R. J. Barry. 2001. Routledge encyclopedia of international political economy: Vol. 1: entries A-F. London: Routledge.

Killough, Hugh B. 1938. International trade. New York: McGraw-Hill.

Kjeldsen-Kragh, Søren. 2002. International economics: trade and investment. Copenhagen: Copenhagen Business School Press.

Kobatsch, Rudolf. 1907. Internationale Wirtschaftspolitik: Ein Versuch Ihrer Wissenschaftlichen Erklärung auf Entwicklungsgeschichtlicher Grundlage. Wien: Manz.

Koo, Wǒn-hoe, and Philip Lynn Kennedy. 2005. International trade and agriculture. Malden (MA): Blackwell.

Krugman, Paul R. 1990. Rethinking international trade. Cambridge (MA): MIT Press.

Krugman, Paul R. 2002. Development, geography, and economic theory. Cambridge (MA): MIT Press. 
Krugman, Paul R., and Maurice Obstfeld. 2009. International economics: theory and policy. Boston: Pearson Addison-Wesley.

Kurz, Heinz D. 1992. Adam Smith on foreign trade: a note on the 'vent-for-surplus' argument. Economica, 59 (236): 475-481.

Kurz, Heinz D. 1998. Ökonomisches Denken in klassischer Tradition: Aufsätze zur Wirtschaftstheorie und Theoriegeschichte. Marburg: Metropolis-Verlag.

Litman, Simon. 1923. Essentials of international trade. New York: Wiley.

Magnusson, Lars. 2004. The tradition of free trade. London: Routledge.

Maneschi, Andrea. 1998. Comparative advantage in international trade: a historical perspective. Cheltenham (UK): Edward Elgar.

Mankiw, Nicholas Gregory, and Mark P. Taylor. 2006. Economics. London: Thomson Learning.

Markusen, James R., James R. Melvin, William Hutchison Kaempfer, and Keith E. Maskus. 1995. International trade: theory and evidence. New York: McGraw-Hill.

Mehmet, Ozay. 1999. Westernizing the third world: the Eurocentricity of economic development theories. London: Routledge.

Merton, Robert King. 1973. The sociology of science: theoretical and empirical investigations. Chicago: University of Chicago Press.

Mill, John Stuart. 1965 [1848]. Principles of political economy: with some of their applications to social philosophy: Books III-V and Appendices. In Collected works of John Stuart Mill, Vol. 3, ed. John M. Robson. Toronto: University of Toronto Press.

Mill, John Stuart. 1967 [1844]. On the laws of interchange between nations; and the distribution of the gains of commerce among the countries of the commercial world. In Collected works of John Stuart Mill, Vol.4: Essays on economics and society, ed. John M. Robson. Toronto: University of Toronto Press, 232-261.

Myint, Hla. 1958. The "classical theory" of international trade and the underdeveloped countries. The Economic Journal, 68 (270): 317-337.

Myint, Hla. 1977. Adam Smith's theory of international trade in the perspective of economic development. Economica, 44 (175): 231-248.

Peng, Mike W. 2011. Global Business. Mason (OH): South-Western Cengage Learning.

Reinert, Kenneth A., and Ramkishen S. Rajan. 2009. The Princeton encyclopedia of the world economy: Vol. 1: A-H. Princeton (NJ): Princeton University Press.

Rorty, Richard. 1984. The historiography of philosophy: four genres. In Philosophy in history: essays on the historiography of philosophy, eds. Richard Rorty, J. B. Schneewind, and Quentin Skinner. Cambridge (UK): Cambridge University Press, 49-75.

Rutherford, Donald. 2000. Routledge dictionary of economics. London: Routledge.

Salvatore, Dominick. 2011. International economics: trade and finance. Hoboken: Wiley. Samuelson, Paul A. 1948. Economics: an introductory analysis. New York: McGraw-Hill.

Sinclair, Huntly M. 1932. The principles of international trade. New York: Macmillan.

Skinner, Quentin. 1969. Meaning and understanding in the history of ideas. History and Theory, 8 (1): 3-53.

Smith, Adam. 1976 [1776]. An inquiry into the nature and causes of the wealth of nations $[W \mathrm{~N}]$. In The Glasgow edition of the works and correspondence of Adam Smith, Vol. 2, eds. R. H. Campbell, and A. S. Skinner. Oxford: Oxford University Press. 
Smith, Adam. 1978a [1762]. Early draft of part of the wealth of nations. In The Glasgow edition of the works and correspondence of Adam Smith, Vol. 5, eds. Ronald L. Meek, D. D. Raphael, and Peter Stein. Oxford: Oxford University Press, 562-581.

Smith, Adam. 1978b [1772-1766]. Lectures on jurisprudence. In The Glasgow edition of the works and correspondence of Adam Smith, Vol. 5, eds. Ronald L. Meek, D. D. Raphael, and Peter Stein. Oxford: Oxford University Press.

Södersten, Bo. 1970. International economics. New York: Harper \& Row.

Söllner, Albrecht. 2008. Einführung in das Internationale Management: Eine Institutionenökonomische Perspektive. Wiesbaden: Gabler.

Staley, Charles E. 1973. A note on Adam Smith's version of the vent for surplus model. History of Political Economy, 5 (2): 438-448.

Staley, Charles E. 1989. A history of economic thought: from Aristotle to Arrow. Oxford: Blackwell.

Stigler, George J. 1958. Ricardo and the 93\% labor theory of value. The American Economic Review, 48 (3): 357-367.

Stigler, Stephen M. 1980. Stigler's law of eponymy. In Science and social structure: a Festschrift for Robert K. Merton, ed. Thomas F. Gieryn. New York: New York Academy of Sciences, 147-157.

Ströbele, Wolfgang, and Holger Wacker. 2000. Außenwirtschaft: Einführung in Theorie und Politik. München: Oldenbourg.

Taussig, Frank W. 1927. International trade. New York: Macmillan.

Tribe, Keith. 1999. Adam Smith: critical theorist? Journal of Economic Literature, 37 (2): 609-632.

Tribe, Keith. 2006. Reading trade in the 'wealth of nations'. History of European Ideas, 32 (1): 58-79.

Viner, Jacob. 1931. Cost curves and supply curves. Zeitschrift für Nationalökonomie, 3 (1): 23-46.

Viner, Jacob. 1937. Studies in the theory of international trade. New York: Harper \& Brothers.

Wasserman, Max J., and Charles W. Hultman. 1962. Modern international economics: a balance of payments approach. New York: Simmons-Boardman.

West, Edwin G. 1988. Developments in the literature on Adam Smith: an evaluative survey. In Classical political economy: a survey of recent literature, ed. William O. Thweatt. Boston: Kluwer Academic Publishers, 13-44.

Wexler, Imanuel. 1968. Fundamentals of international economics. New York: Random House.

Wildmann, Lothar. 2010. Einführung in die Volkswirtschaftslehre, Mikroökonomie und Wettbewerbspolitik. München: Oldenbourg.

Winch, Donald. 1978. Adam Smith's politics: an essay in historiographic revision. Cambridge: Cambridge University Press.

Yarbrough, Beth V., and Robert M. Yarbrough. 2006. The world economy: trade and finance. Mason $(\mathrm{OH})$ : Thomson-South-Western.

Young, Allyn A. 1928. Increasing returns and economic progress. The Economic Journal, 38 (152): 527-542.

Young, John P. 1938. International trade and finance. New York: Ronald Press.

Zhang, Wei-Bin. 2008. International trade theory: capital, knowledge, economic structure, money, and prices over time. Berlin: Springer. 
Ziegler, Bernd. 2008. Geschichte des Ökonomischen Denkens: Paradigmenwechsel in der Volkswirtschaftslehre. München: Oldenbourg.

Reinhard Schumacher is a $\mathrm{PhD}$ candidate and works as a research fellow at the University of Potsdam, Germany. His main research interests are history of economic thought, international political economy and trade theory.

Contact e-mail: <rschumac@uni-potsdam.de> 